\title{
地質踏査でデジタルガジェットを使いこなす： その2クリノメーター
}

\section{要 旨}

地質踏査の三種の神器の一つであるクリノメーターについて, 古典的アナログ機器といえる国内外の製品版クリノメーターを紹介する と共に，現在ダウンロード可能な同機能アプリ（iOS抄よびアンドロイド版）について，デジタルガジェットとして紹介する。

Key words：クリノコンパス Geological Compass, トランシット Transit Compass, アプリ app

\section{1.はじめに}

地質踏査の三種の神器といえば，ハンマー, クリノメー ター, フィールドノート (野帳) である。クリノメーター については，アナログ機器を利用されている方もまだ多い と思われるが，スマートフォン用アプリでの利用も可能で ある.スマートフォンには総称でMEMS（Micro Electro Mechanical Systems；微小な電気機械システム）とよば れる，電子コンパスやジャイロセンサーが搭載されており， アプリをインストールすることで計測機器としての利用が 可能である。 この原稿では古典的アナログ機器である数種 類の製品版クリノメーターを紹介すると共に, 現在ダウン ロード可能な同機能アプリについても紹介する.

ところでクリノメーターをアルファベット表記すれば Clinometerとなるが，逆に英語のClinometerを和訳すると 傾斜計となり，方位を測る意味は無くなる。すなわちクリ ノメーターは和製英語であり, 英語圈ではPocket Transit Compass $^{1)}$ やGeological Compass ${ }^{2)}$ という名称が主流であり， Brunton Compassという製品名でも通用することが多い. トランシットコンパスとは，方位と傾斜が測定できる測量 器具であり，日本では牛方製ポケットコンパスがよく利用 されている。トランシットやセオドライトといえば角度を さらに精度よく測定できる測量機器であり，コンパスであ る方位磁針はついていない.さらにセオドライトに光波測 距儀を組み合わせたものをトータルステーションと呼ぶこ

* (公財) 深田地質研究所 Fukada Geological Institute（会 員)

現所属：名城大学 理工学部 社会基盤デザイン工学科 Department of Civil Engineering, Meijo University e-mail : fujii@meijo-u.ac.jp

** 中央開発(株) Chuo Kaihatsu Corp.（会員）
とが多い。また後述するクリノコンパスをアルファベット 表記すればClino-compassとなり，これも和製英語である が，こちらの方が英語圈で意味が通じそうである。

\section{2. 製品版クリノメーター}

\section{1 木製・金属製クリノメーター（日本）}

最もシンプルなクリノメーターである（写真-1）。木製
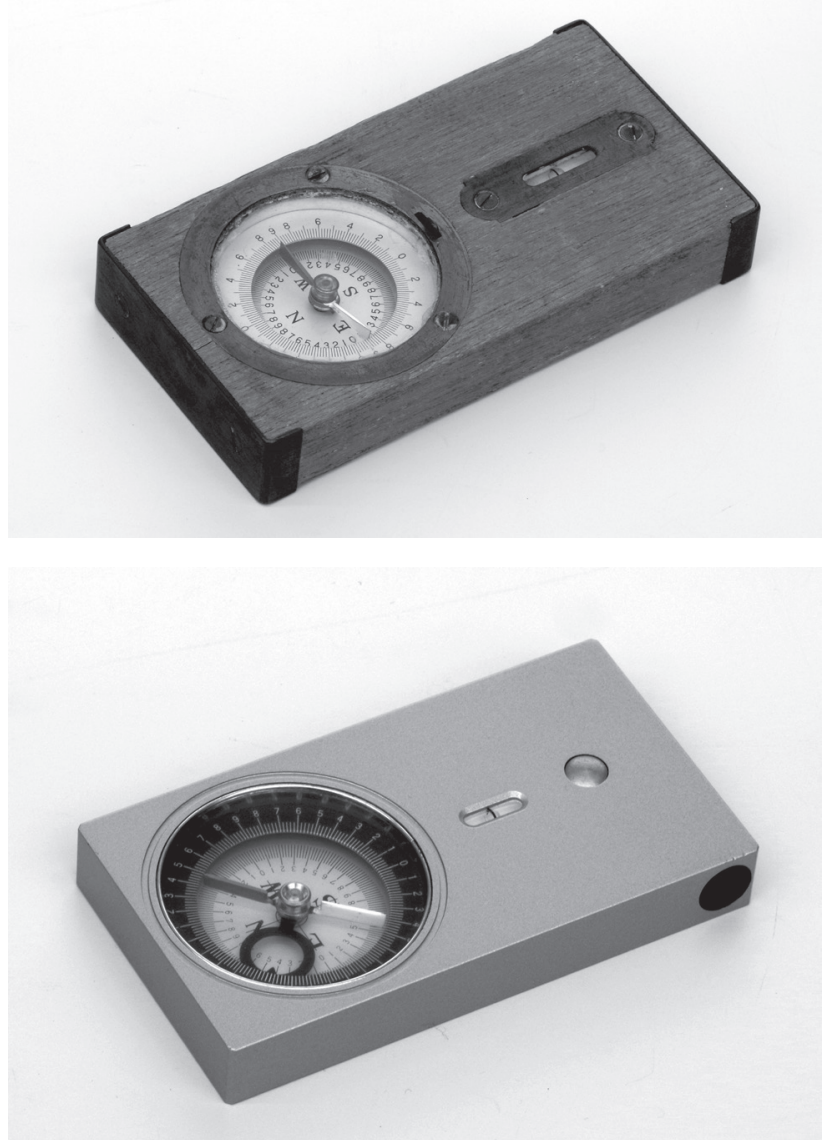

写真-1 木製（上）と金属製（下）クリノメーター 
は既に販売されていない，方位と傾斜を測定でき，平型の 水準器が一つついている，安価で初心者向きとされるが, 後述のクリノコンパスと比べると軸受けがやや弱く, 故障 しやすい様である，木製は水に浮くので重宝されていた． 側面の指標を伸ばして見通しで傾斜を計測することも可能 である。

\section{2 クリノコンパス深田式（日本）}

深田式とあるのは, 樑田地質研究所で開発されたためで ある. 故大矢暁氏 (元深田地質研究所, 元応用地質 (株) ) が中心となり，木製クリノメーターを基に，ブリキと手鏡 を組み合わせたプロトタイプを作成し，これを各種調査で 利用したそうである。そこで皆が使えて売れるようなもの をつくろうという目的で，図面を描いた経緯がある。その 際，ドイッのクランプ社製クリノメーターを参考にしたよ うである。図面を昭和測器工作所に持ち込み，さらに改良 を加えてできたのが，クリノコンパス梁田式である（写真 -2)。 クリノメーターの簡便さと, ブラントンコンパスの 精度とを合わせた意味が込められている(以上は羽田 ${ }^{3)}$ よ り要約)。さらに真偽の程は定かでないが，クリノコンパ スの完成版ができた際，製品30個と引き替えに，昭和測器 に設計図を渡したそうである。

クリノメーターとの大きな違いは，蓋代わりの鏡とその 逆側に指標が搭載されていることである。これを利用すれ ば，ルートマップ作成時に次の目標を定める際にも, 通常 のクリノメーターに比べて高い精度が得られる。ところで ルートマップも和製英語であり，英語でroute mapといえ ば道路地図を示すことが多い，英語ではtraverse mapと いった方がよいようである。またルートマップを作る際, 歩測による距離の誤差よりも，コンパスによる方位誤差の 方が大きくなる゙)。クリノコンパスはこの誤差を減らそう とした試みの製品かもしれない.

残念ながら昭和測器は廃業し，その後も(株)二チカが販

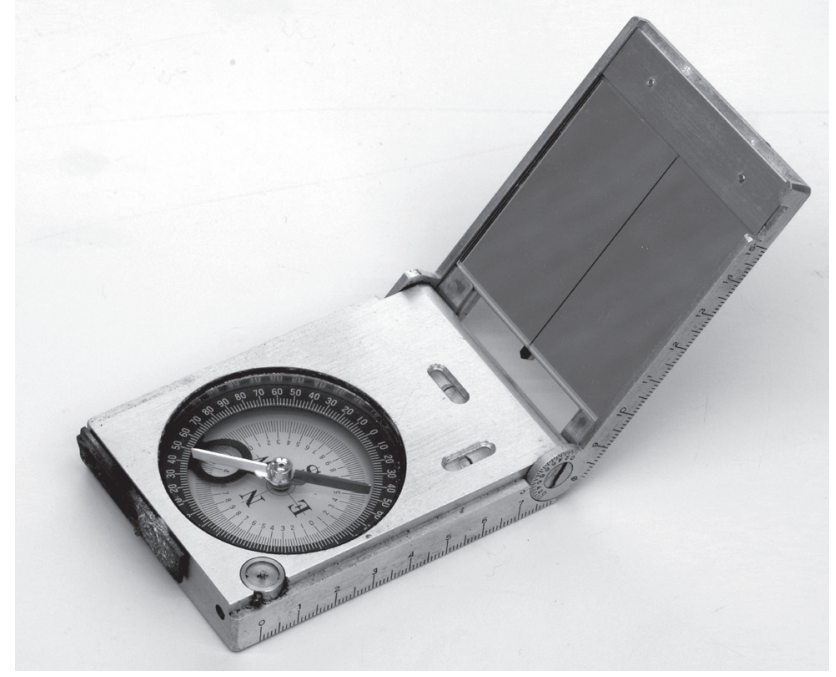

写真-2クリノコンパス深田式
売や修理を続けていたが，現在は入手することができない

2.3 ブラントンコンパス (Brunton Compass，アメリ カ合衆国・コロラド州)

カナダ生まれの地質屋打よび鉱山屋であるD.W. BRUNTONにより，1894年コロラド州デンバーに創業し たBrunton社の製品である（写真-3），正式名称はPocket Transit Compassであり，現在はいくつかの種類が販売さ れている. 水準器は方位測定用の丸形と, 傾斜測定時の平 型が登載されており，方位も傾斜も $1^{\circ}$ 刻みの目盛がある。 アルミ製で防水も施されており，丈夫なつくりである，蓋 代わりの鏡が搭載されており，鏡と逆側に搭載された指標 と共に使用すれば, クリノコンパス同様に高い精度が得ら れる。日本製クリノメーターは東西南北で表示される $90^{\circ}$

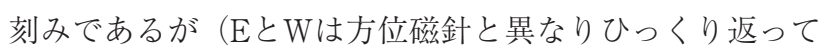
(る)，ブラントンコンパスは反時計回りの $360^{\circ}$ 表示であ る。米国では走向を $360^{\circ}$ 表記で行うことが多いためである。 これは時計回りで常に右側が傾斜方向を示す表示となって いる (right hand ruleと呼ばれている)。しかしコンパス の下には東西南北形式の表示もされている.

世界的に有名な機器であるため, 模造品も大変多い. 中 国ハルピン製のものや，オマーンで入手できるBrinton Compassが深田地質研究所に展示されている。

\section{4 ブライトハウプト (BREITHAUPT KASSEL, ド イツ)}

折りたためる蓋付きの装置であるが，蓋に鏡はついてい ない (写真-4) . 蓋を構造面に当てて丸型の水準器で水平 をとることで，傾斜方向の方位と傾斜角度を同時に測定で きる，方位磁針は普段固定されて抢り，隅にある固定具を 動かすことで方位磁針が動く構造となっている，方位は左 回りの $360^{\circ}$ に，東西南北の表記もある，方位板が透明なた め，裏側からも測定ができる構造になっている．

\section{5 ブッソルシェイ (Boussole Chaix, フランス)}

折りたたんで仕舞える構造となっており，片側に方位磁 針と丸型水準があり，もう片側に傾斜計が内蔵されている

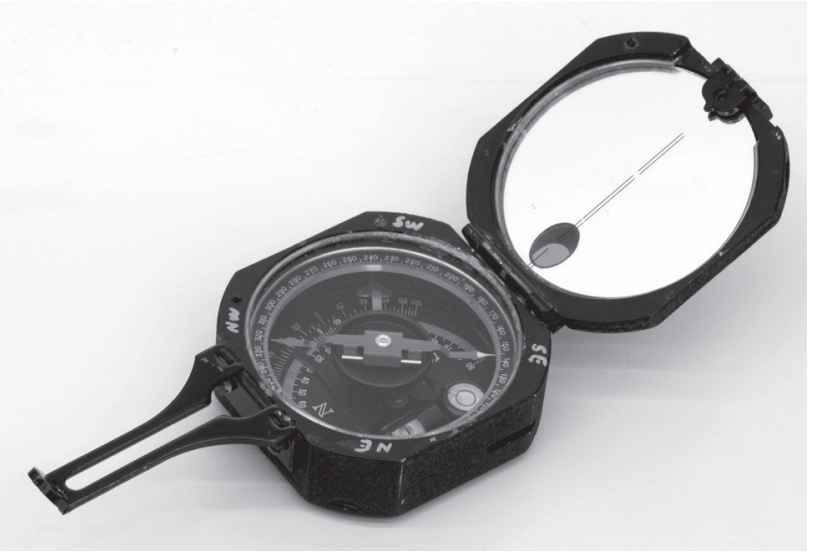

写真-3ブラントンコンパス 
(写真-5上). 指標も搭載されており, クリノコンパス同様 に見通しも精度よく測定できる。折りたたんで閉じると磁 針が静止するのも, クリノコンパスやブラントンコンパス と同様な機能である。方位の目盛は, $360^{\circ}$ で右回りも左回 りも記載されており, さらに内側に東西南北でも記載され ている. フランス人の手に合わせてなのか, 大変大きくて 丈夫な作りになっている，方位と傾斜が一つに集約された 簡易版も存在する（写真-5下）.

\section{6 プラスティック製コンパス（傾斜計付）}

シルバ (スウェーデン), スウント (フィンランド), レ クタ (スイス) 等のヨーロッパのメーカーから販売されて いる。このうちスンウトとレクタは1996年に経営統合して 現在はスウントが製品を製造している。オリエンテーリン グや軍事活動に使うことを想定に開発されたため, 方位は 時計回りの $360^{\circ}$ 表記となっており, 地質踏査に用いる際は

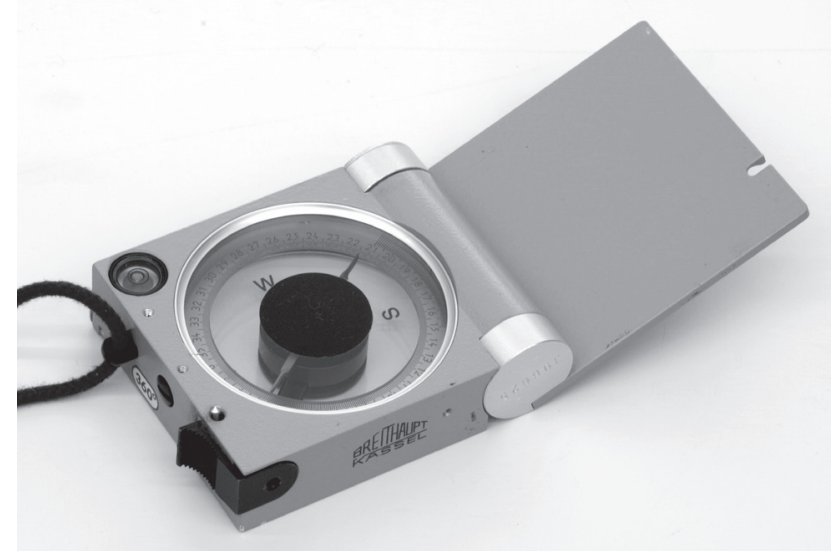

写真-4ブライトハウプト
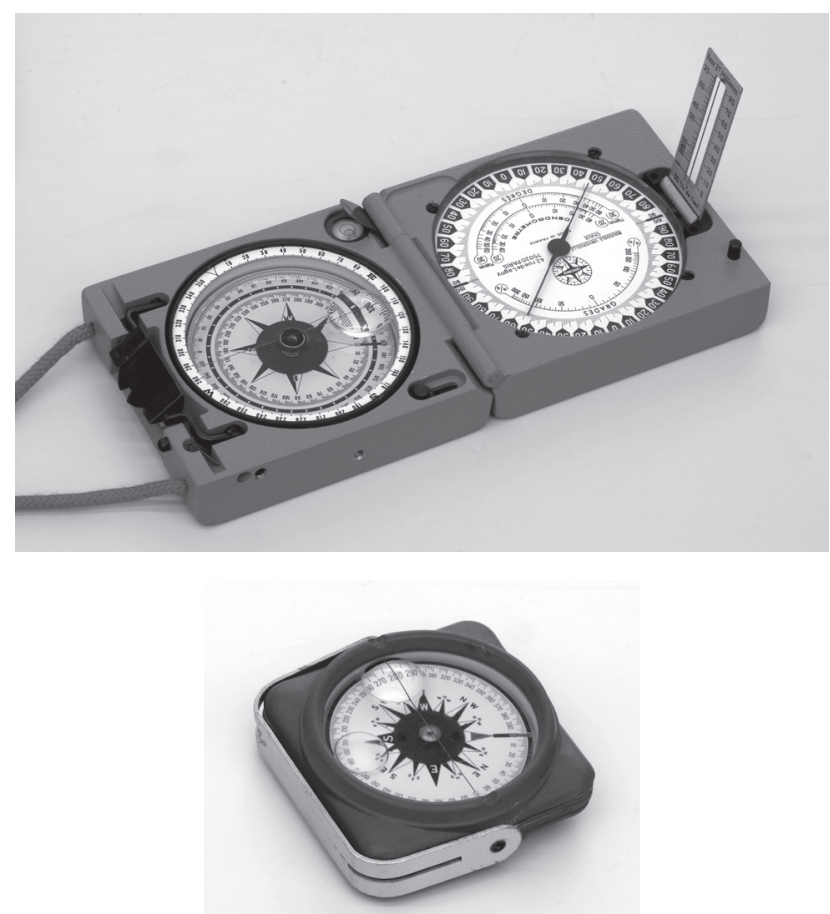

写真-5 ブッソルシェイ（上）と簡易版（下）
注意が必要である。この表記をシールなどで東西南北表記 や反時計回りの表記に代えて販売されているケースもある オイル封入式のため磁針がピタッと止まる, 水にぬれても 問題なく，軽くて扱いやすいなどのメリットがある。ただ し水に浮かないものが多い. 鏡面を有する蓋付きや, シン プルなものなど形状は数種類存在するが, どれも透明板を 利用しているので裏からも測定が可能である（写真-6 8 ） また水準器も丸型や平型など搭載されているものが様々あ り，オイル封入されたコンパス自身に気泡が入れられて水

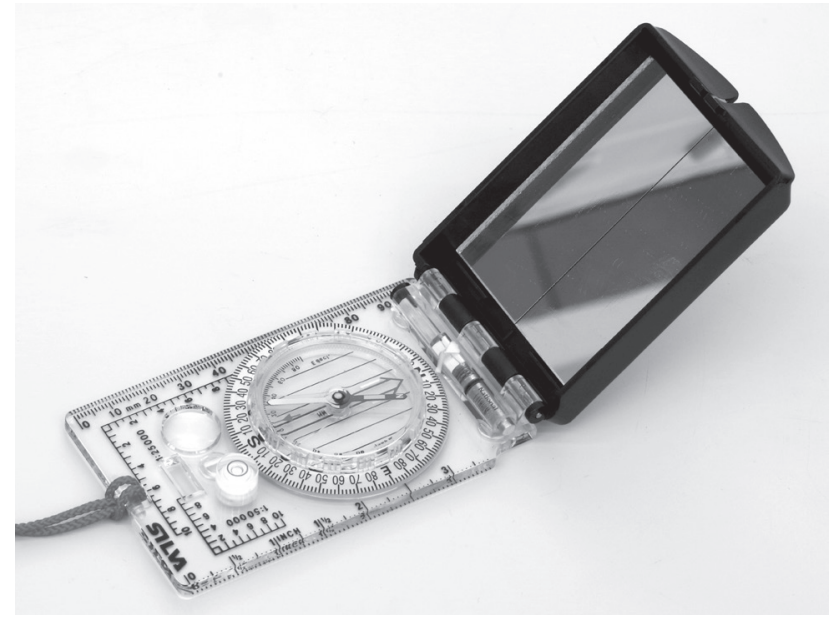

写真-6 シルバコンパス

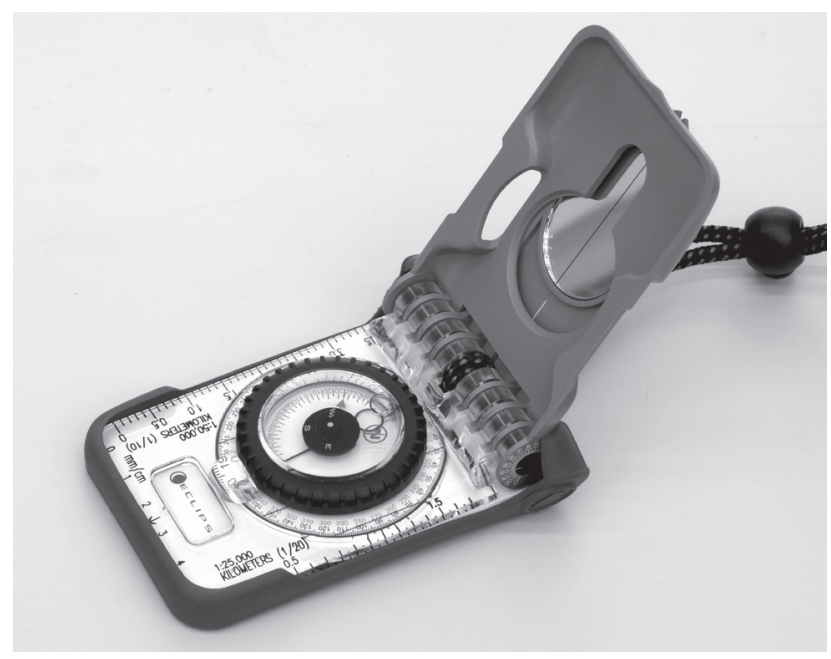

写真-7 シルバ・エクリプス

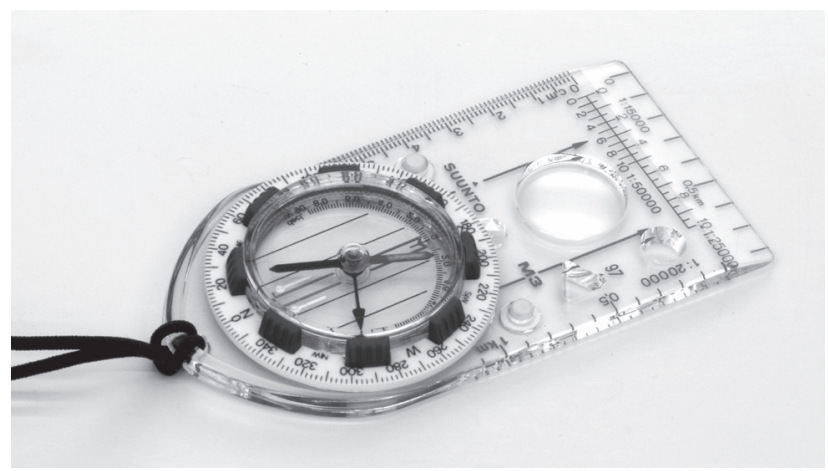

写真-8 スウント 
準器の役割を担っているものもある. “liquid filled matchbox" modelといわれる小型のものを著者は携帯する ことが多いが $($ 写真-9)，これは1941年にレクタが発明し たもので，マッチ箱の大きさであるが簡易測量にも利用で きるものである。このモデルはスイス軍に採用されて相当 数が出荷されたようであるが, 第二次世界大戦後は登山や オリエンテーリングでの利用が増えたようである.

\section{7 デジタルクリノメーターGeoClino（GSI社，日本）}

2007年頃の販売. 通常版とGPS付版が販売されていた(写 真-10). 現在は販売されて扮らず，後述のアプリ版が後継 となっている，通常版でも5 万円近くの值段で，クリノコ ンパスの 2 倍ほどであった。 キャリブレーションを行う煩 わしさはあるものの，構造面に当てるだけですぐに計測が できる，同時に記録もできるので大変便利である，同じ時 間内で，通常のクリノコンパスの 3 倍は計測できそうであ る。ただしインターフェースが数值のみの表示となり（走

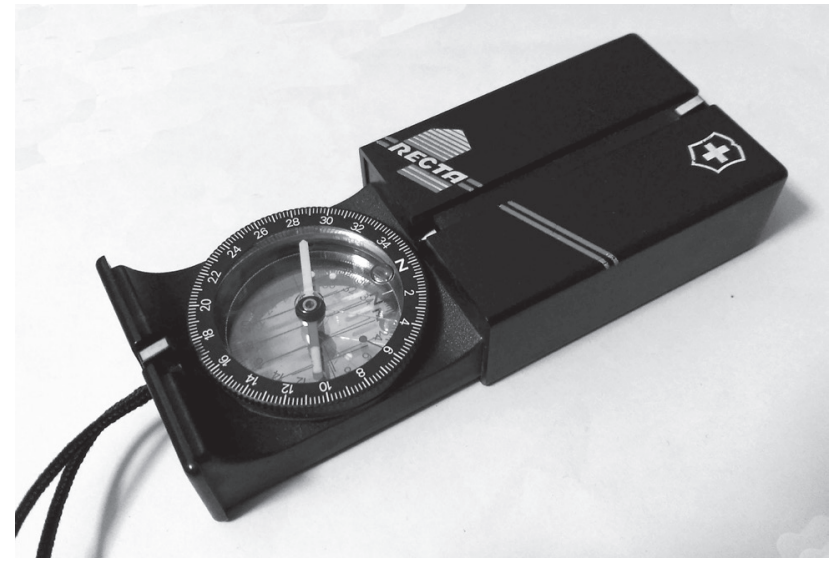

写真-9 レクタ “liquid filled matchbox” model

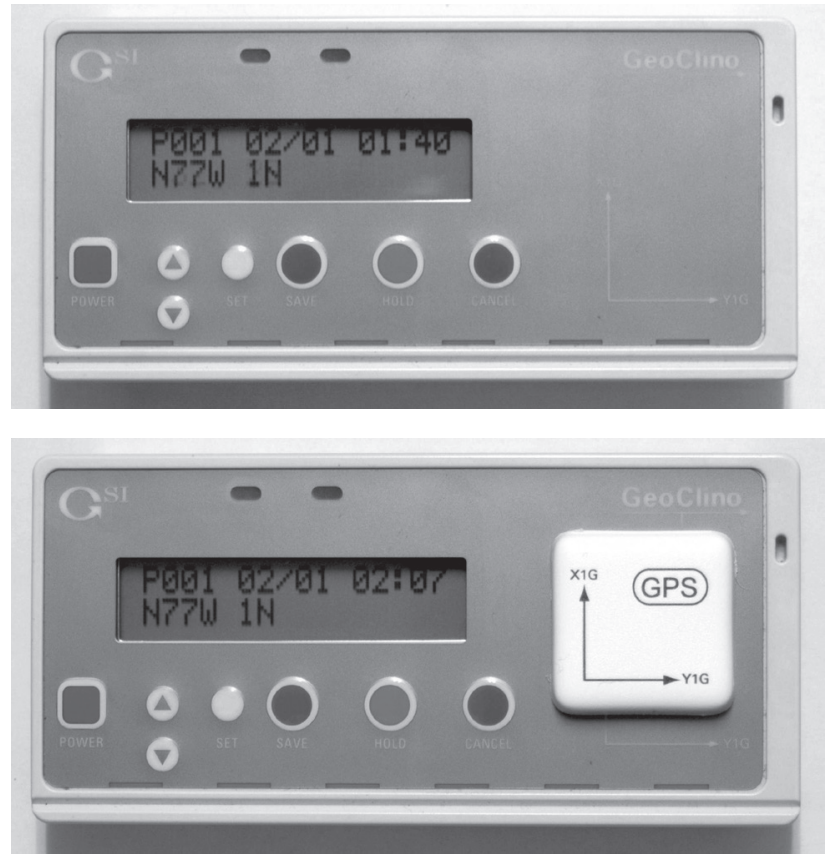

写真-10 デジタルクリノメーターGeoClino（GSI社製）
向傾斜と線構造と日時などが表示される), クリノコンパ ス等のGUI（Graphical User Interface）に慣れてしまった 著者には使いづらかった。たとえば $N 77^{\circ} \mathrm{W}$ と示されるわ けだが，北はどちらかな？と考えていると，結局クリノコ ンパスを持ち出してしまう始末である。この点は下記のア プリ版で解決されているといえよう。

\section{3. アプリ版クリノメーター}

国内外で様々なアプリが開発されており，ダウンロード 可能である，以下に 3 つを紹介する。国内製アプリ 2 件と 海外製アプリ 1 件である．下記以外にもいくつかの海外製 アプリが存在するようであるが ${ }^{11,2,5)}$ ，似たような機能であ るので興味を持った方はGoogle PlayやApp Storeで検索さ れたい．またこれらのアプリと製品版の古典的なコンパス を比較した報告があり ${ }^{5)}$ ，傾斜に大きな差はないが，方位 は最大で80度も異なったとしている。 スマートフォンや夕 ブレットといったハードウェアとアプリの相性，あるいは ハードウェアのデジタルコンパスの問題を指摘している. 実際にデジタルコンパスはキャリブレーションが必要で, いくつかの方法が提案されている(6) 8). いずれにせよ利用 の際はキャリブレーションなど，十分気を付ける必要があ ろう。

\subsection{Geoclino for Android（GSI社製）}

製品版，Lite版の二種類が用意されており，それぞれ $¥ 3,980 ， ¥ 100$ あるる（写真-11は製品版），どちらも走向 傾斜や線構造を測定でき，500点まで記録が可能で，記録 したデータを出力してメール送信することもできる，製品 版とLite版の機能の違いは, 衛星測位を利用して計測点を 地図上に表示したり，軌跡を記録することができ，さらに

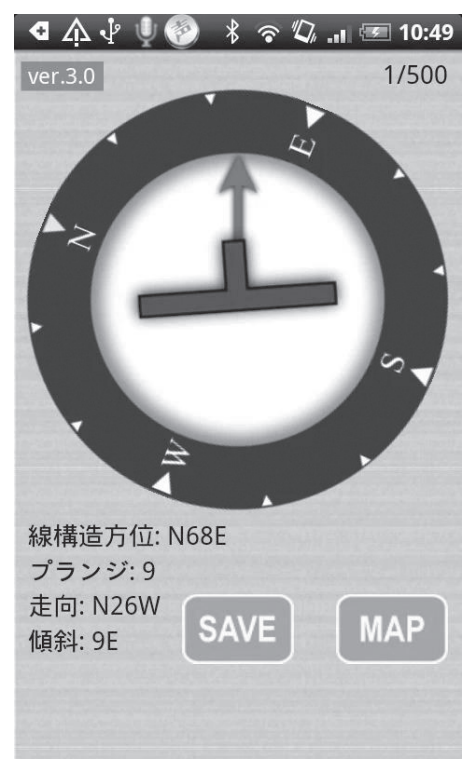

写真-11 Geoclino for Android (Google Play)

https://play.google.com/store/apps/details?id=gsi. geoclinoAndroid\&hl=ja 


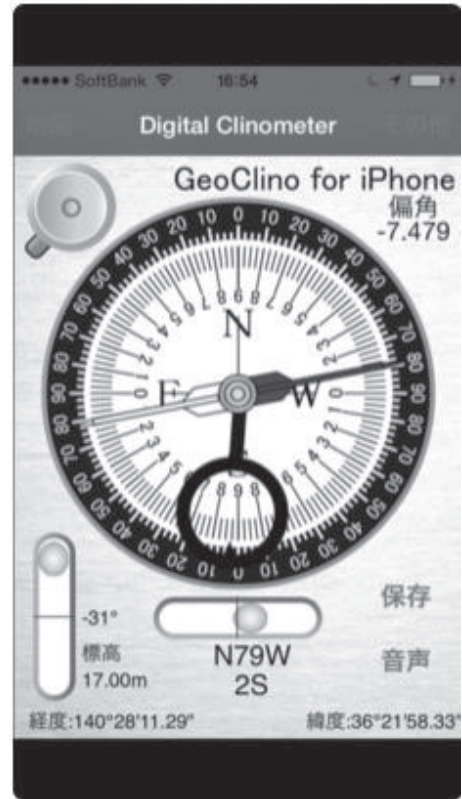

写真-12 Geoclino for iPhone (App Store)

https://itunes.apple.com/jp/app/geoclino-for-iphone/ id 398949364 ? $\mathrm{mt}=8$

測定データをスマホ画面でシュミットネット上に表示する ことも可能である. 写真-11のようなGUIを持っており, 北方向もわかりやすく表示してくれる。

\subsection{Geoclino for iPhone（産業技術総合研究所）}

走向傾斜や線構造を測定・記録でき，記録したデー夕を 出力してメール送信することもできる。衛星測位を利用し て計測点を地図上に表示したり記録することもできる（写 真-12)。すなわちGeoclinoのiOS版といえ，GSI社が受託開 発を行っている。無料アプリである。利用してみればわか るが，GUIはクリノコンパス深田式を意識したものになっ ている.

\subsection{Pocket Transit (R\&W Scientific)}

Geoclino for Andloid 同様に，走向傾斜や線構造の測定 と記録が可能で，記録したデータをCSV形式に出力するこ ともできる（写真-13）。衛星測位を利用して計測点を地図 上に表示したり，記録することもでき，さらに測定データ をスマホ画面でシュミットネット上に表示することも可能 である. $360^{\circ}$ 表示の外周と内部に東西南北表示で丸型水準 器を示すGUIは, ブラントンコンパスを意識しているよう にみられる。これだけの機能がついて無料というのは, Geoclino for iPhone同様に驚きである.

\section{4. おわりに}

日本で製品版クリノメーターを購入する場合，金属製の クリノメーターでも 1 万円ほどした覚えがある。ましてや クリノコンパス深田式になると 2 万円を優に超えていたは ずである。これに比べるとアプリ版クリノメーターは無料 から数千円で手に入る。ももちんスマートフォンを持って

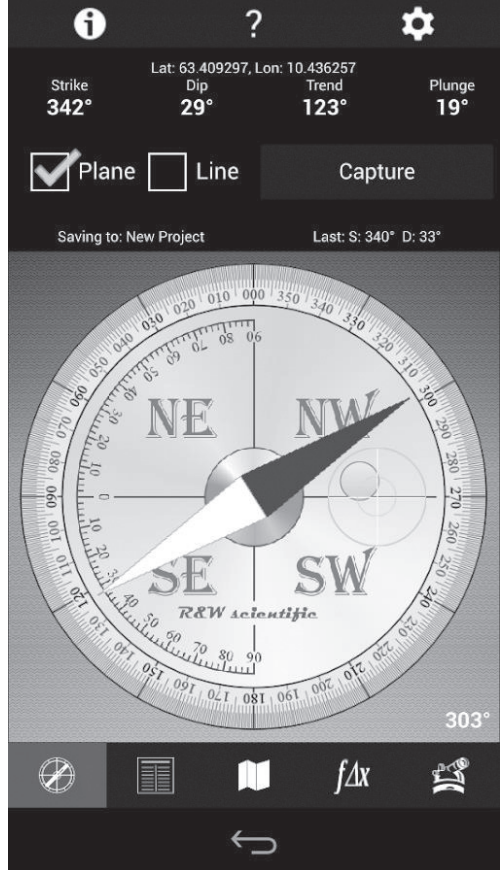

写真-13 Pocket Transit（Google Play）

https://play.google.com/store/apps/details?id=com. rwscientific.pockettransit

いればの話であるが，現在の携帯電話普及率を考慮すれば, 大学生以上であればほぼ一一台の所有率といえよう。す なわち特別な投資を必要とせず，地質屋の三種の神器の一 つが手に入り，誰でも簡単にクリノメーターを使える。さ らに地質や土木といった $3 \mathrm{~K}$ （きつい，きたない，きけん） の業界において，ICT技術の活用はイメージアップにもつ ながるだろう。この業界の将来的な発展を考慮すれば，前 回の野帳も含めて, 地質踏査にデジタルガジェットを積極 的に取り入れていく姿勢が必要ではないかと感じる.

謝辞 ここに紹介したアナログ機器の製品版クリノメー ターのほとんどは, 深田地質研究所元理事長で筑波大学名 誉教授の佐藤正博士のコレクションである. 深田地質研究 所にご寄贈頂いたものを撮影して利用させて頂いた。 また クリノコンパス深田式については，藤田勝代博士に資料の 捜索などお願いした。さらにデジタルクリノメーターやア プリ版のクリノメーターに関しては，開発会社であるジー エスアイ(株) (GSI社) からコメントや画像等を頂いた。 ここに記して感謝申し上げます.

\section{引 用 文 献}

1) Weng, Y., Sun, F. and Grisby, J.D. (2012) : GeoTools: An android phone application in geology. Computer \& Geoscience, Vol.44, pp.24-30.

2) Novakova, L. and Pavlis, T.L. (2017) : Assessment of the precision of smart phones and tablets for measurement of planar orientations: A case study. Journal of Structural 
Geology, Vol.97, pp.93-103.

3）羽田 忍（1967）：クリノコンパス誕生，扔拈よう，第19号.

4) 佐藤 正 (1970): マッピングの精度について, 地質学雑誌, Vol.76, pp.613-622.

5) Lee, S., Suh, J. and Park H. (2013) : Smart CompassClinometer: A smartphone application for easy and rapid geological site investigation. Computer \& Geoscience, Vol.61, pp.32-42.

6) Bonnet, S., Bassompierrea, C., Godina, C., Lesecq, S. and Barraud, A. (2009) : Calibration methods for inertial and magnetic sensors. Sensors and Actuators A: Physical,
Vol.156, pp.302-311.

7) Luo, S., Pang, H., Li, J., Zhang, Q., Chen, D., Pan, M. and Luo, F. (2013) : Calibration strategy and generality test of three-axis magnetometers. Measurement, Vol.46, pp.39183923.

8) Pang, H., Pan, M., Chen, J., Li, J., Zhang, Q. and Luo, S. (2016): Integrated calibration and magnetic disturbance compensation of three-axis magnetometers. Measurement, Vol.93, pp.409-413.

（2018年 4 月27日受付，2018年 8 月10日受理）

Jour. Japan Soc. Eng. Geol., Vol.59, No.4, pp.219-224, 2018

\title{
Using Digital Gadgets in Geological Survey : Part 2 Pocket Transit Compass
}

\author{
Yukiyasu FUJII and Yutaka KANZAKI
}

\section{Abstract}

Key words : Geological Compass, Transit Compass, app 